\title{
Biometry of neotropical invertebrates inhabiting floodplain rivers: unraveling bionomy
}

\author{
Florencia Zilli, Julia del Barco \& Agustín Vanzetti
}

\begin{abstract}
Currently, it is widely recognized that invertebrates play key roles in neotropical floodplains and in many other environments worldwide. However, little information has been published concerning their biometry, in spite that it represents an essential tool for many different studies. Here, we provided length-mass and length-length relationships by fitting the linearized model $\left(\log _{10} \mathrm{Y}=\log _{10} \mathrm{a}+\mathrm{b} \log _{10} \mathrm{X}\right)$ and several mean biomass ratios \pm SE for bivalves, gastropods, quironomids, ephemeropterans, oligochaetes and hirudineans. We measured, weighed, oven dried and incinerated to ashes specimens collected from 2005 to 2014 in the Paraná River, Argentina. The lineal equations had fit levels higher than $75 \%$ in most of the significant regressions. Hence, when slopes were compared, differences raised from ontogeny and phylogeny of taxa. Additionally, slopes resulted different from constants of other regions, types of environments and climates. In addition, organic matter ratios resulted significantly different among invertebrates according to their feeding types. The equations and ratios that we provided will facilitate future research on life history, productivity and energy transference in the food webs of invertebrates inhabiting floodplain wetlands and can be used as tools for planning management strategies and in restoration projects of aquatic environments.
\end{abstract}

KEYWORDS. Allometry, organic matter, Paraná River, wetlands, benthos and pleuston.

RESUMEN. Biometría de invertebrados de ríos de llanura: desentrañando su bionomía. Actualmente, es muy reconocido que los invertebrados tienen un rol clave en los ambientes de llanura aluvial neotropicales así como en otros ambientes alrededor del mundo. Sin embargo, se cuenta con muy poca información publicada en relación con su biometría, a pesar de ser una herramienta esencial para muchos tipos de estudios. En este trabajo se obtuvieron relaciones longitud-masa ajustadas por el modelo linearizado $\left(\log _{10} \mathrm{Y}=\log _{10} \mathrm{a}+\mathrm{b} \log _{10} \mathrm{X}\right)$ y diferentes proporciones de materia orgánica promedio \pm ES para bivalvos, gastrópodos, quironómidos, efemerópteros, oligoquetos e hirudíneos. Medimos, pesamos, secamos e incineramos hasta cenizas especímenes colectados entre 2005 y 2014 en el río Paraná, Argentina. Las ecuaciones lineales tuvieron valores de ajuste mayores al $75 \%$ en la mayoría de las regresiones significativas. Al comparar las pendientes, se encontraron diferencias relacionadas con la ontogenia y filogenia de las taxa. Asimismo, las pendientes resultaron diferentes de las constantes para otras regiones, tipos de ambientes y climas. Asimismo, las proporciones de materia orgánica fueron significativamente diferentes entre invertebrados de acuerdo a su tipo de alimentación. Las ecuaciones y proporciones que obtuvimos facilitarán futuras investigaciones sobre historia de vida, productividad y transferencia de energía en las tramas tróficas de invertebrados en humedales de llanura aluvial y pueden ser empleadas para planificar estrategias de manejo y en proyectos de restauración de ambientes acuáticos.

PALABRAS-CLAVE. Alometría, materia orgánica, río Paraná, humedales, bentos y pleuston.

Having a thoughtful knowledge of aquatic ecosystems requires an evaluation of the structure and functioning of its components. Thus, as macroinvertebrates play an important role in food webs and matter cycling in most aquatic systems, is essential to count with tools to study their biomass and productivity. Actually, biomass is a key variable in quantifying a variety of ecological processes at any of the organization levels in either aquatic or terrestrial environment, ranging from individual consumption and bioenergetics to the spatial transfer of energy between habitats (BENKE et al., 1999).

However, direct determination of fresh or preserved mass is not feasible in many cases such as when estimation of biomass of small and abundant animals is too laborious and time consuming and when rare specimens cannot be destroyed. Moreover, differences on live mass of aquatic organisms might reflect not only differences in biomass, but differences on water retention, thus direct determination of dry mass is recommended in order to obtain reliable estimates of biomass (Donald \& PATERSON, 1977).

Length-dry or wet mass conversion is one of the most used techniques for estimating biomass from samples when direct measurement is neither possible nor practical (BENKE et al., 1999). Indeed, this method is usually considered better to others (i. e. biovolume determinations or direct weighing) primarily because results faster and more precise (ROGERS et al., 1976; BURGHERR \& MEYER, 1997). However, lengthmass relationships obtained for invertebrates in a specific region or type of environment are not generally transferable to other study sites (MEYER, 1989). The length-mass analyses have been widely used and tested for mass estimations of 
terrestrial, benthic and planktonic invertebrates from other biogeographic regions (mostly compiled in SMOCK, 1980; Benke et al., 1999 and JoHnston \& CUnJAK, 1999 for North America, Towers et al., 1994 for New Zealand, MEYER, 1989, Burgherr \& MEYER, 1997 for Europe). Even though the importance of biometry, few data are available just for aquatic as well as terrestrial neotropical insects (CRESSA \& LEWIS JR., 1984; CressA, 1986, 1999; LóPEZ et al., 1997; ZILLI et al., 2008, 2009), whereas most data were obtained for the other macroinvertebrate groups, of streams in cold climates (AlbARIÑo \& BALSEIRO, 1998; MisERENDINO, 2001; GUALDONI et al., 2013). Furthermore, there are scarce studies on biometry and available information on such relationships for most aquatic invertebrate groups inhabiting floodplain wetlands.

Many invertebrates inhabiting the Paraná River floodplain - such as worms, leeches, midges, mayflies, bivalves and snails- are widespread across similar rivers of tropical regions. In wetlands of the Paraná River they are benthic or associated to macrophytes, with high abundance and richness (PoI DE NeIfF \& NeIFF, 2006; EzCURRA DE DrAGo et al., 2007). In addition, they can reach high biomass and secondary production (ZILLI, 2012, 2013; ZILLI \& PAGGI, 2013) and link basal sources with higher trophic levels (GALIZZI et al., 2012; SAIGo et al., 2015).

In spite of their ecological importance for rivers functioning, there is still a lack of published information concerning biometry of neotropical macroinvertebrates. Moreover, in the frame of increased river perturbations worldwide in a global warming scenario, it becomes essential to obtain information concerning such relationships in relatively unaltered systems such as the Middle Paraná River, prior to management and conservation strategies development. In this frame, our objective was to provide length-mass relationships and to assess the ratios of organic (ash free) mass for some of the common groups of macroinvertebrates inhabiting large rivers and to enable ecologist to count with biomass estimates that are generally highly suitable for ecosystem functioning studies.

\section{MATERIALS AND METHODS}

The biometric relationships were obtained for mollusks, midges, aquatic worms, mayflies and leeches collected in the frame of different studies from 2005 through 2014 from ponds, streams, rivers, and temporary wetlands very closely located to 2 RAMSAR sites (31 $37^{\circ}$ '52”S $60^{\circ} 30^{\prime} 45^{\prime \prime} \mathrm{W}$ and $31^{\circ} 53^{\prime} 34^{\prime} \mathrm{S}$ - 6040’36”W, Paraná River floodplain, Argentina, Table I). All these taxa comprise the most frequent and abundant invertebrates found in the Paraná River and other neotropical large rivers. Invertebrates were collected with dredges and nets from benthos and pleuston respectively, fixed with $10 \%$ formalin and preserved in $70 \%$ ethanol solution.

Measurements, biomass an organic matter obtention. Total body length or some other dimension (Tab. I) was measured using a optic microscope supported with a micrometric scale (accurate to $0.001 \mathrm{~mm}$ ) for the smaller invertebrates and a digital caliper for the higher organisms (Schwiz, Electronic Digital Caliper, accurate to $0.01 \mathrm{~mm}$ ). For all the taxa we aimed to ensure that, a wide size range was included in the measurements.

The wet weight, hereafter named as WW (in mg), was obtained after soaking the invertebrates for ten minutes in water and drying in a piece of blotting paper for some seconds. The dry weight, hereafter called DW (in mg) was obtained after oven dry at $60^{\circ} \mathrm{C}$ for $72 \mathrm{hs}$ to constant, and then cooling in a desiccator. The WW and DW estimations only approximate organic matter if the weights of calcareous skeletons and/ or body moisture are eliminated (STIRN, 1981), biomass for mollusks is presented both with and without shells, except in the case of Planorbidae and Sphaeriidae, as it was impossible to separate soft form hard parts.

It has been widely studied that preservatives such as alcohol, cause changes in the weight of preserved animals, which may affect weight estimates. Therefore, in the present study, compensations were made for changes in weight by using the factors reported by LEUVEN et al. (1985).

The ash free dry weight biomass, hereafter AFDW (mg), was obtained for invertebrates. Some mollusks were weighed individually, whereas other invertebrates were pooled into groups before weighing. After dry weight was obtained as described above, the samples were muffle furnace at $500^{\circ} \mathrm{C}$ for $3 \mathrm{hs}$ (LAPPALAINEN \& KANGAS, 1975). In every case, before weighing, the animals were cooled down to room temperature in a desiccator equipped with absorbent packets of silica gel. The AFDW was calculated by subtracting the ash-weight from the DW.

The biomass measurements were obtained by using either an OHAUS balance (Model ANALYTICAL Plus) or Mettler Toledo (model AB204-S/FACT) balance (Accuracy: 0.01 and $0.1 \mathrm{mg}$ respectively), according to the sample and balance accuracy.

Data analysis. The lineal regression describes $\mathrm{Y}$ as function of $X$ within the range of observed values of $X$ and, therefore, generally it is an unsafe procedure to predict $\mathrm{Yi}$ values from $\mathrm{Xi}$ values outside the observed range of $\mathrm{Xi}$ (ZAR, 1996). Hence, when estimations should be performed out of the ranges of regressions, then proportions may represent a useful tool. Therefore, in the present paper, several mean ratios \pm SE are presented.

Prior to run the statistical analysis, data were explored for outliers, linearity and homoscedasticity (Box-plots, QQplots and Breusch-Pagan test). The lineal coefficients that better fit to the relationships among metrics and biomass data, the $\mathrm{R}^{2}$ and significance values were obtained. Data were $\log _{10} \mathrm{x}+1$ transformed to better fit the lineal equations in the form: $\log _{10} Y=\log _{10} a+b \log _{10} X$.

Comparisons were made for fit values and slopes of dimensions-mass and dimension-dimension regressions and organic matter proportions, either with Kruskal-Wallis, Mann-Whitney and Wilcoxon tests. The statistical analyses were run by using the R VERSION 3.1.2 and PAST version 2.17c (HAMMER et al., 2001). Additionally, the ratios among different metrics were calculated. 
Tab. I. Habitat and measurements made for different invertebrates of the Parana River floodplain, Argentina. The structures measured on each group together with the abbreviations which will be utilized are described below.

\begin{tabular}{|c|c|c|}
\hline Taxa; abreviations & Habitat & Description of linear metrics measured \\
\hline Hirudinea (Leeches); Hir & $\begin{array}{l}\text { Associated both, to } \\
\text { macrophytes and benthos }\end{array}$ & $\begin{array}{l}\text { Body contraction due to fixation may conduct to highly biased } \\
\text { measurements Thus, lineal measurements were not included } \\
\text { in this study }\end{array}$ \\
\hline $\begin{array}{l}\text { Oligochaeta (Aquatic worms); Oli } \\
\text { Opistocystidae (Opistocysta } \text { spp. and } \\
\text { Trieminentia corderoi Harman, 1969); Op } \\
\text { Tubificininae (Aulodrilus pigueti Kowalewski, } \\
\text { 1914; Ap, Limnodrilus spp.; Lim) }\end{array}$ & $\begin{array}{l}\text { Associated to macrophytes, } \\
\text { but mainly to benthos }\end{array}$ & $\begin{array}{l}\text { L: Total length measured from the anterior edge of the } \\
\text { prostomium to the posterior edge of the last segment } \\
\mathrm{W} \text { : average of } 3 \text { measurements made in the first, mid and last } \\
\text { segments, perpendicularly to the main body axis }\end{array}$ \\
\hline $\begin{array}{l}\text { Bivalvia (Clams); Biv } \\
\text { Corbiculidae (mainly the non-native } \\
\text { Corbicula fluminea Müller, 1774); Cor }\end{array}$ & Infaunal benthic clams & $\begin{array}{l}\mathrm{L}: \text { in a lateral view, measured from the anterior to the } \\
\text { posterior border of the shell }\end{array}$ \\
\hline $\begin{array}{l}\text { Sphaeriidae (mainly Musculium spp. and } \\
\text { Pisidium spp.); Sph }\end{array}$ & $\begin{array}{l}\text { Associated to macrophytes, } \\
\text { but mainly to benthos }\end{array}$ & $\begin{array}{l}\text { H: in a lateral view, from the top of umbo to the ventral } \\
\text { border of the shell. }\end{array}$ \\
\hline $\begin{array}{l}\text { Hyriidae (Castalia ambigua Lamarck } \\
1819 \text { and Diplodon spp., mainly } D . \\
\text { parallelopipedon Lea, 1834); Hyr }\end{array}$ & Infaunal benthic clams & $\begin{array}{c}\text { W: in a dorsal view, measured perpendicularly to } \mathrm{H} \text { in the } \\
\text { wider section of each specimen }\end{array}$ \\
\hline $\begin{array}{l}\text { Gastropoda; Gas } \\
\text { Ampullaridae (Apple snails, mainly Pomacea } \\
\text { canaliculata Lamarck 1828, and Asolene } \\
\text { spp.); Amp }\end{array}$ & \multirow[t]{2}{*}{$\begin{array}{l}\text { Benthic, but mainly associated } \\
\text { to macrophytes Amphibious }\end{array}$} & $\begin{array}{l}\mathrm{H}=\text { from the tip of the apex to the further border of the outer lip. } \\
\mathrm{D} 1 \text { : In a ventral view, measured at the wider section of the } \\
\text { body whorl } \\
\text { D2: measured, in a } 90^{\circ} \text { angle to D1. }\end{array}$ \\
\hline $\begin{array}{l}\text { Planorbidae (Ramshorn snails, Biomphalaria } \\
\text { spp., Drepanotrema spp.); Pla }\end{array}$ & & D: in a lateral view, measured across the wider section \\
\hline $\begin{array}{l}\text { Ephemeroptera (Mayflies); Eph } \\
\text { Polymitarcidae, mainly Campsurus violaceus } \\
\text { Needham \& Murphy, } 1924\end{array}$ & $\begin{array}{l}\text { Nymphs mainly from benthos, } \\
\text { but also from pleuston }\end{array}$ & $\begin{array}{l}\text { L: from the anterior edge of the head to the posterior edge of } \\
\text { the last abdominal tergite } \\
\text { Tibia: measured in the fore leg tibia from the articulation with } \\
\text { the femur to the end of the tibia projection. } \\
\text { Interoc: in a dorsal view of the head, measured from eye to eye }\end{array}$ \\
\hline $\begin{array}{l}\text { Chironomidae (Midges); Ch } \\
\text { Chironominae: Chironomus spp., Cladopelma } \\
\text { spp., Saetheria } \text { spp., Harnischia } \text { spp.; Chir } \\
\text { Tanypodinae: Coelotanypus spp., Ablabesmyia } \\
\text { spp., Tanypus spp.; Tany }\end{array}$ & $\begin{array}{l}\text { Aquatic larvae inhabiting } \\
\text { benthos and pleuston }\end{array}$ & $\begin{array}{l}\text { L: in a dorsal view, measured across the body from the tip of } \\
\text { the labrum to the end of the last abdominal segment } \\
\mathrm{cW} \text { : measured perpendicularly to } \mathrm{L} \text { at the maximum width of } \\
\text { the cephalic capsule }\end{array}$ \\
\hline
\end{tabular}

\section{RESULTS AND DISCUSSION}

Invertebrate biometry by lineal models. We present new Lineal to DW and Lineal to Lineal dimension regressions based on either total body length or shorter dimensions (e.g., head width) in Appendices I and II. Additionally, detailed information is showed concerning data (n), significance level (p), metric ranges, fit level $\left(=\mathrm{R}^{2}\right)$ and lineal coefficients for each equation.

Most of the significant regressions that we obtained explained more than $75 \%$ of the DW variation due to increments in the lineal metrics, with just a few ranging from $25 \%$ to $50 \%$ fit (Fig. 1). This high fit level was also obtained for several regressions by other authors (SMOCK, 1980; Burgherr \& Meyer, 1997; Benke et al., 1999; Cressa, 1999; Miserendino, 2001; GuALdoni et al., 2013).

Furthermore, also other models were tested. Indeed, L-DW relationships fitted best to polynomial regressions even after $\log 10(\mathrm{x}+1)$ transformations of data. However, in most of the cases, differences of $\mathrm{R}^{2}$ among one or higher order power regressions were of just $1 \%$ of the DW variability explanation (i. e. $\mathrm{R}^{2}$ were relatively higher in smooth curves than more lineal ones), except for midges and mayflies that had a $12 \%-25 \%$ and $2 \%$ differences. Indeed, discontinuous growth by moulting is most compatible with sharp breaks in allometry. Thus, when freshwater arthropods molt, they suddenly increase their body volume without increasing their DM (the cast exuviae actually represents a loss of mass). This point may introduce variability into length-mass regressions as animals of the same body dimensions may vary considerably in their DM. This is probably the case, mainly for holometabolous insects such as midges, which larvae grow sharply between instars.

On the other hand, individual growth is usually estimated from a mass sample of individuals in various growth stages and thus any sudden spurt occurring at varying sizes in different individuals will be damped to a more gently curved transition in the mass data regression (GouLD, 1966). This compound allometry were also found in other studies for mayflies and it had been explained in terms of the nymphs passing from immature to mature stages, when the ratios of specific growth rates changed due to an increasing rate of development of imaginal structures (CLIFFORD, 1970). Conversely, from a large number of relationships investigated 


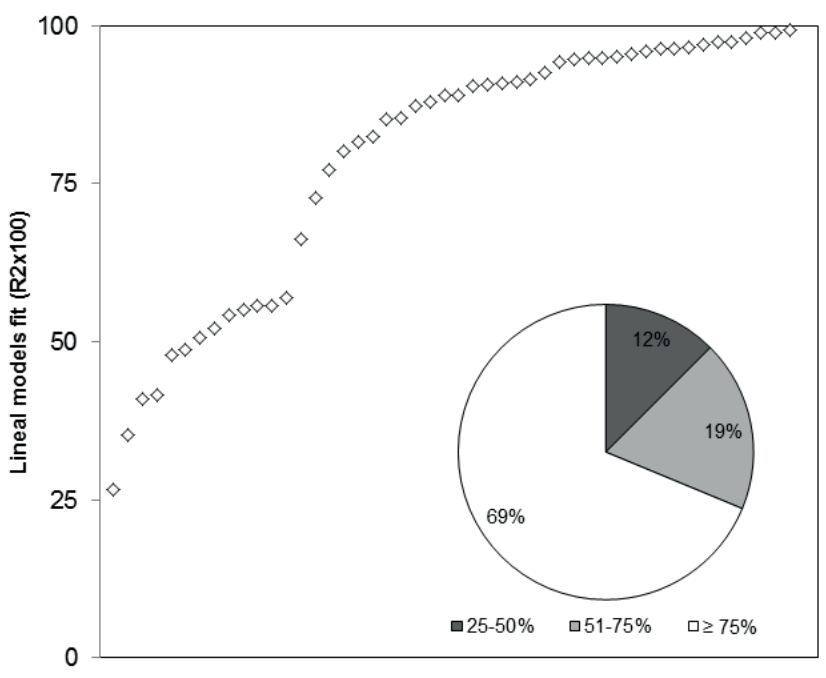

Fig. 1. Lower to higher fit level $\left(\mathrm{R}^{2}\right)$ for the lineal models on metric-DW variation of invertebrates. The pie-chart shows the proportion $(\%)$ of values that fall within each $\mathrm{R}^{2}$ category. Invertebrates were collected in the Paraná River floodplain from 2005 through 2014.

for mayflies, only $32 \%$ cases of isometry were found as, in most cases, the change in the allometric relationship late in nymphal life did not occur at the same total body length for all of the dimensions investigated (CAMPBELL, 1991). Actually, in our study, isometry was not obtained for mayflies (Appendix II) and thus sharp changes in biomass as nymphs grow might be related to differences in allometry within each instar.

Additionally, closer fits can always be obtained by adding further terms to a power series (VON BERTALANFFY, 1964). However, choosing a reasonably simple functional expression involving the minimum of non-interpretable parameters it would be essential to increase biological understanding (SCHOLL, 1954) and thus, the lineal function has enjoyed almost exclusive use in allometric studies.

Generally, length was the metric that best fitted to biomass changes for all the taxa and thus, $\log _{10}$ plots are showed on Figures 2-5. However, width and mass were also highly correlated for mollusks and mayflies. Conversely, lower fit levels were obtained for worms and for midges in contrast with results reported for these insects by other authors either for terrestrial (Rogers et al., 1976; GowING \& RECHER, 1985) or aquatic species (SMOCK, 1980; WENZEL et al., 1990; Meyer, 1989; Burgherr \& Meyer, 1997; CRessa, 1999).

Growth and allometry: assessing invertebrates bionomy. Most of the regressions showed higher fit levels for mollusks and mayflies than worms and midges (Fig. 6), with even some regressions that didn't even fit such as width-DW for Aulodrilus pigueti, Opistocystidae (both oligochaetes) and Coelotanypus (midges). Moreover, fit values for L-DW and W-DW regressions were statistically different for taxa (Wilcoxon signed rank test, $\mathrm{p}<0.05$ ), with higher values for the former. This might be related to the fact that length usually represents a better measurement of ecological links as reflect resources acquisition (BENKE et al., 1999). The comparisons showed stepped differences for worms but mainly for midges. Indeed, many authors reported that body length performed as a better predictor of biomass than head capsule width for most insects (SMOCK, 1980; Meyer, 1989; Burgherr \& Meyer, 1997). Conversely, the trend was not such clear for mayflies and mollusks that showed also high fit levels for the other dimensions. These results might be directly related to differences in growth type. Indeed, from the data obtained, worms and midges grew more in length than in width, while metrics of mayflies but mainly mollusks showed a higher isometry as it can be observed form slopes (=b) in the Appendix II. Moreover, among clams, the Hyriidae showed lower fit levels, probably because individuals of largely different shaped genera (Diplodon, mainly D. paralellopipedon Lea, 1834 and Castalia ambigua Lamarck 1819) were pooled within the data set, while Sphaeriidae and Corbiculidae resulted more homogenous.

In the case of insects, differences in allometry could be related to the type of preimaginal molts. To accomplish the large increase in mass after molting, much of the cuticle of holometabolous insects remains unsclerotized and undifferentiated. For example, when larval caddisflies molt, the initially soft cuticle of their heads rapidly reaches its instar-specific width and quickly hardens, but the undifferentiated cuticle of their abdomen is somewhat extensible and facilitates more continuous growth and as much as a tripling of mass (BENKE et al., 1999). Indeed, larvae belonging to the holometabolous orders generally have greater within-instar variability in DM related to $\mathrm{CW}$ than those in the hemimetabolous orders, because the former tend to have fewer instars and thus increase more in linear dimensions (and mass) from 1 instar to the next than the Hemimetabola (Cole, 1980; Butler, 1984). Actually, cephalic width is a common metric used to estimate larval instar among midges (DYAR, 1890).

The DW variability of mollusks, was highly explained not only when the whole individuals but also when only soft tissues were considered in every lineal combination $\left(\mathrm{R}^{2} \mathrm{x} 100\right.$ $\geq 80 \%$, Appendix II) with no significant differences between fit levels for both (Wilcoxon signed rank test, $\mathrm{p}>0.05$ ). However, soft tissues accounted for less than $1 \%$ in clams (Hyriidae and Corbiculidae respectively) and $22 \%$ of total weight in apple snails (Appendix III). Thus, as shells are mainly constituted by inorganic materials (on average $95 \pm 2 \%$ is represented by ashes) care must be taken when matter and energy transference are intended. Hence, changes in DW of bivalves as metrics increased were more pronounced considering the whole individuals than only soft tissue, with almost a unit difference for Corbiculidae and less than 0.15 but still positive for Hyriidae (Fig.7). Conversely, for apple snail slopes were higher when DW of soft tissues was regressed against metrics than when the entire specimens were considered. This might probably be explained by the varying calcium intake of clams at different stages of their life cycle, while apple snails might invest more energy on soft tissue. 

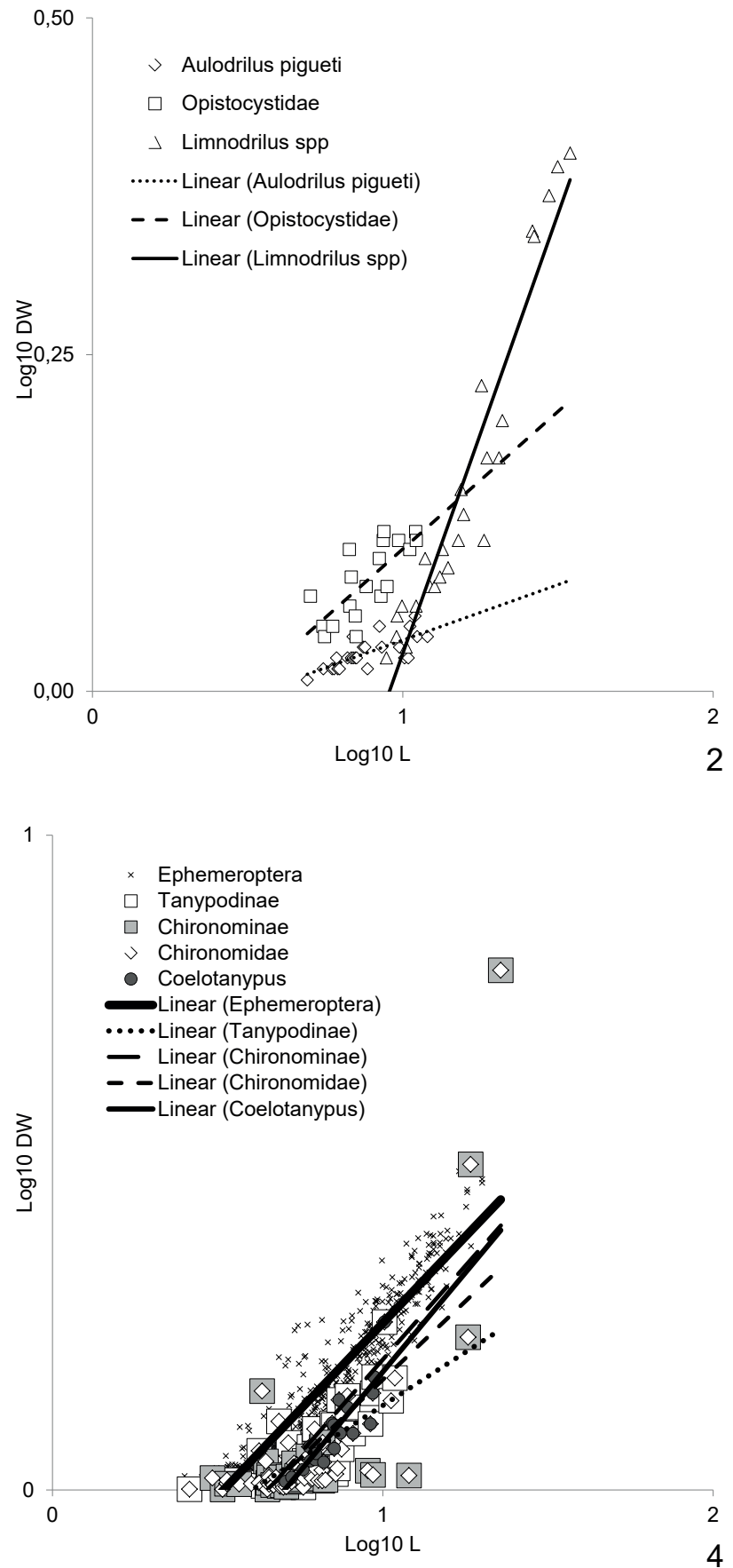
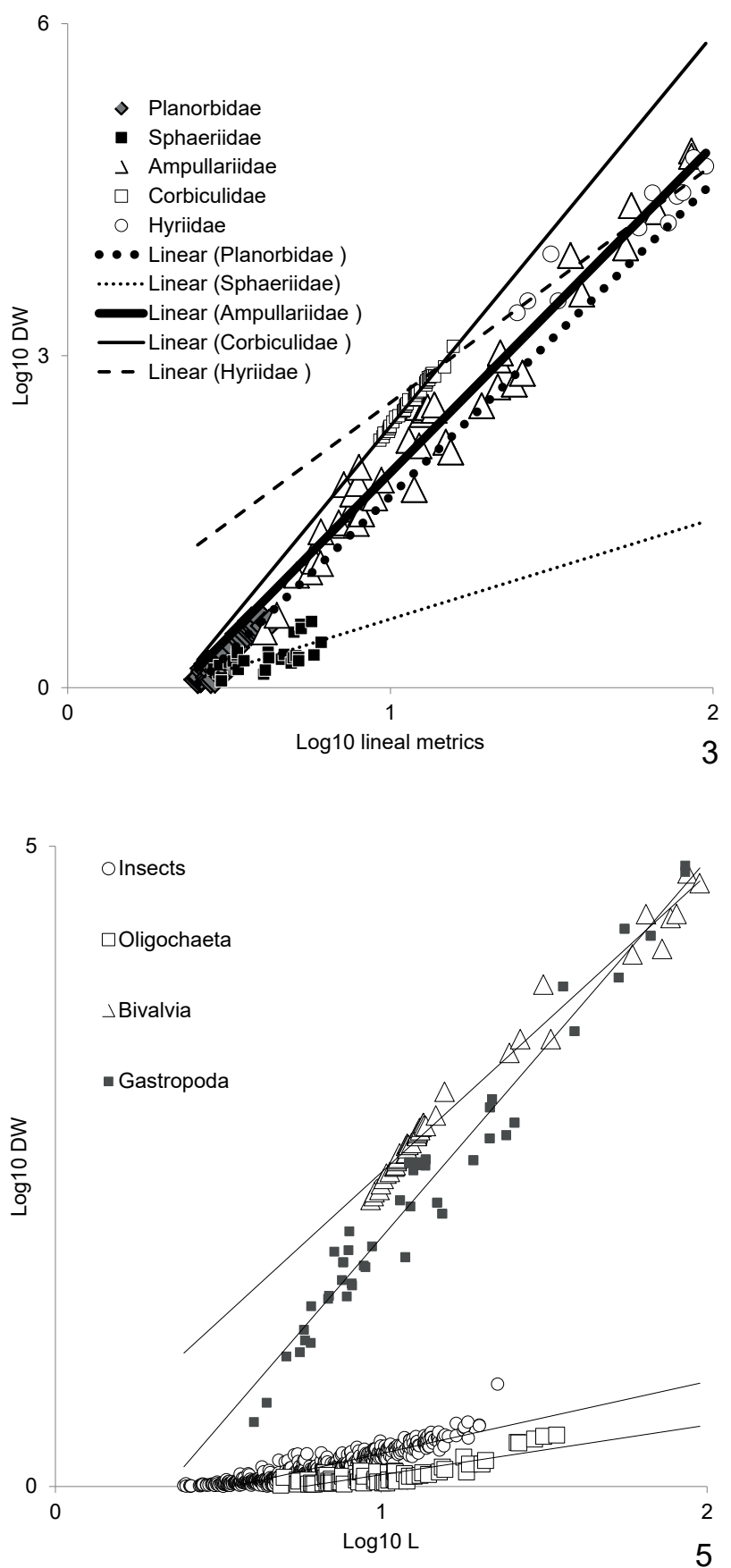

Fig. 2-5. Dispersion plots and lineal curves on L-DW regressions for (2) oligochaetes, (3) mollusks, (4) insects and (5) all invertebrates together. For Planorbidae L=D and for Ampullariidae L= H. In Fig. 5 only apple snails H-DW were considered within "Gastropoda" and only Corbiculidae and Hyriidae (and not Sphaeriidae) were considered within "Bivalvia". Invertebrates were collected in the Paraná River floodplain from 2005 through 2014.

Furthermore, the predictive capability of speciesspecific equations is higher when using equations based on data grouped at higher taxonomic levels (BENKE et al., 1999). In the present study, such trend was obtained for Limnodrilus spp. (oligochaetes) with higher adjusts than all worms pooled, for mayflies in relation to all insects pooled, for midges and when considering all macroinvertebrates pooled. Additionally, differences in slopes among equations would suggest that it is better to use the closest level to avoid errors associated with substitutions.
In most studies, it is supposed that animals grow allometrically and for most of the aquatic invertebrates groups the constant $b$ is often close to a value of 3 even for length and width (BENKE et al., 1999). The underlying assumption for this value is that body mass is more influenced by surface than volume (ENGELMANN, 1961). In our study, $41 \%$ of the obtained constants were 3 or very close while $45 \%$ were $\leq 3$ and only $14 \%$ were $>3$ (Fig. 8 ).

Shape and specific gravity must remain exactly the same throughout development for the expected value of $b$ to 


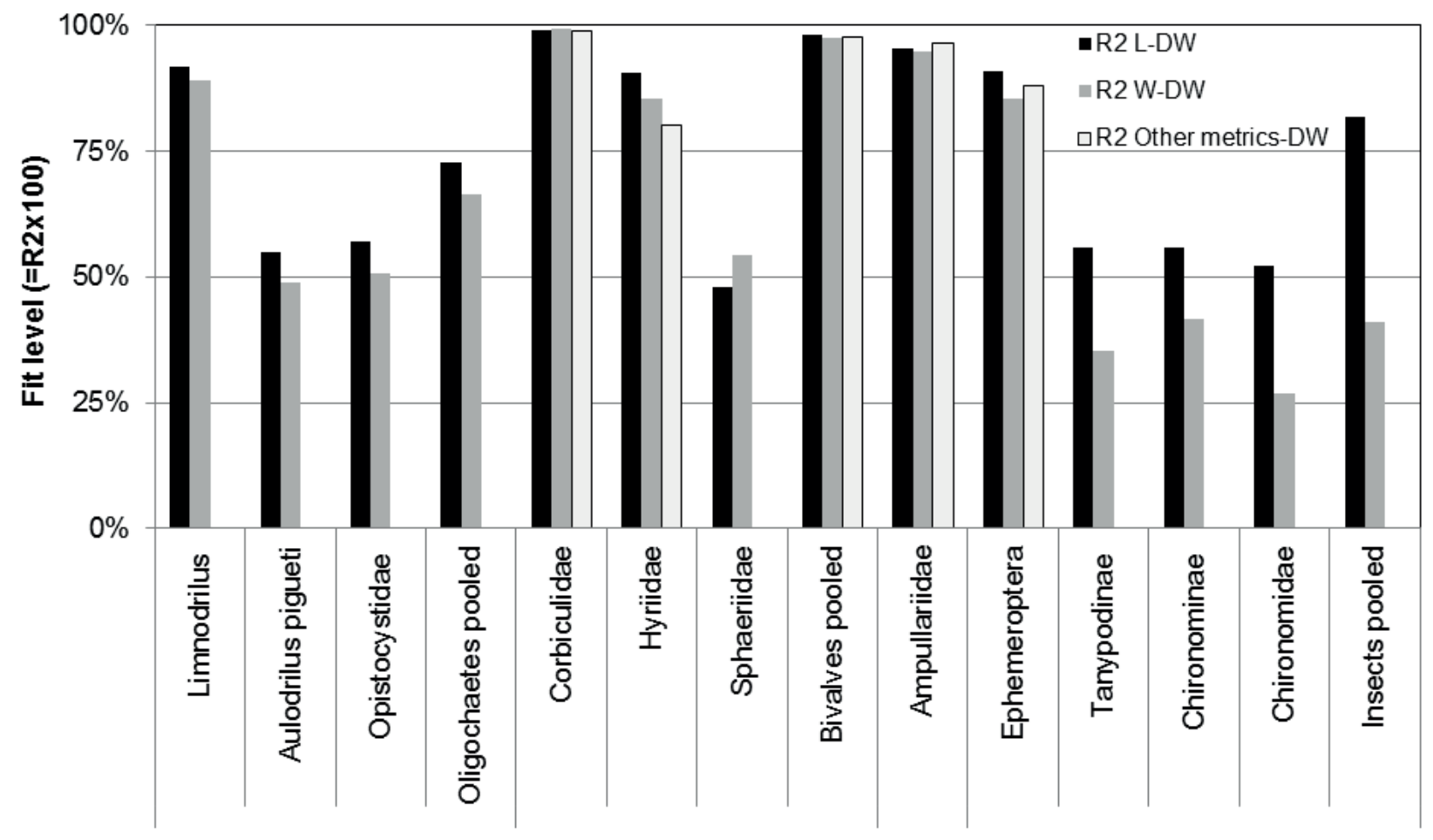

Fig. 6. Fit levels obtained from freshwater invertebrates metric-DW lineal regressions. $L=$ length, W= width and other metrics= "W" for clams, "D2" for apple snails and "Tibia” for mayflies. Invertebrates were collected in the Paraná River floodplain from 2005 through 2014.

be exactly 3 (BENKE et al., 1999). Indeed, our findings for mollusks showed that slopes were very close to 3 when full specimens and only soft parts were regressed against metrics. However, displacements from the perfect cubic relationship were explored. Thus, in our study, mollusks showed an isometric growth of all the metrics along development, with slightly lower slopes just for Hyriidae that must be related to differences in shape changes of the genera involved (Appendix II). Conversely, differences in slopes for both, apple snails and clams, showed that displacement from the perfect cubic relationship could be explained by growth changes in specific gravity. Thus, for clams there was a higher slope when the entire specimens were considered mainly for Corbiculidae (Fig. 7). This seems to be related to a variable rate of material addition to valves along their growth cycle. Opposite, apple snails showed the inverse trend (Fig. 7). This could be related to changes in specific gravity of soft parts due to investment on structures related to reproduction such as penis in males and albumen glands that increase considerably when the female is about to produce eggs. In the case of Sphaeriidae, the equations obtained might have been affected by calcium lost due to fixation and preservation. Therefore, use of these equations should be cautiously made.

Moreover, in our study, values lower than 3 were mostly obtained for worms and insects. For insects, the mean value of $b$ for length-mass equations is actually somewhat $<3$ for all orders, families and individual taxa (compiled in SMock, 1980; Meyer, 1989; Towers et al.,

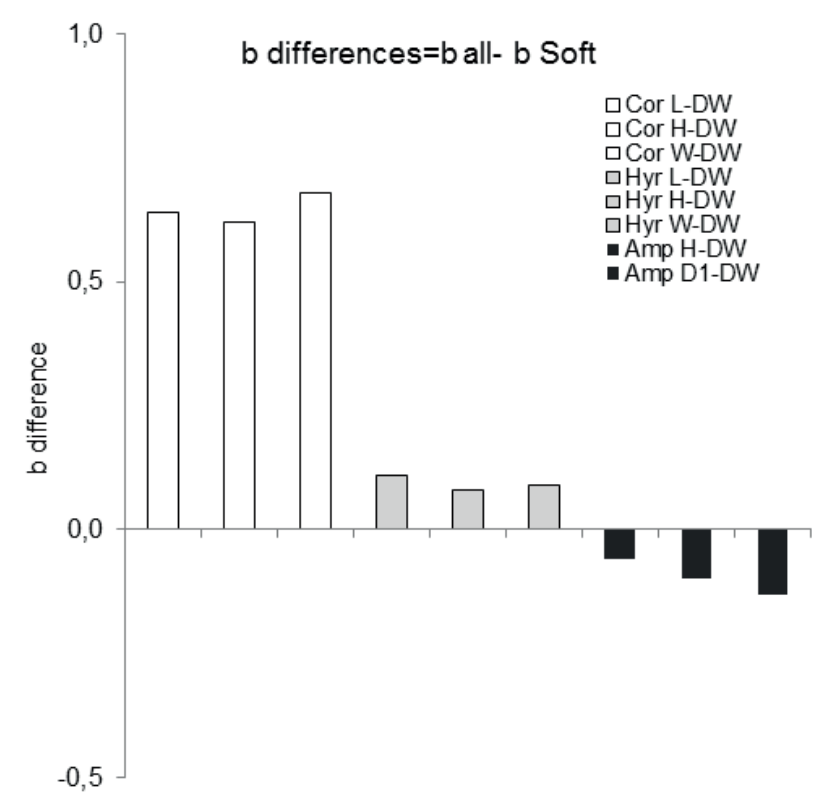

Fig. 7. Differences in slopes obtained for lineal regressions of mollusks with and without shells. Invertebrates were collected in the Paraná River floodplain from 2005 through 2014.

1994; Burgherr \& Meyer, 1997). On the other hand, several authors reported values $<3$ for several invertebrates across different environments of the neotropics (CRESSA, 1999; BeCKer et al., 2009; GUALdoni et al., 2013). The reasons why the mean value of $b$ would be consistently $<3$ for insects and oligochaetes are either that these invertebrates 


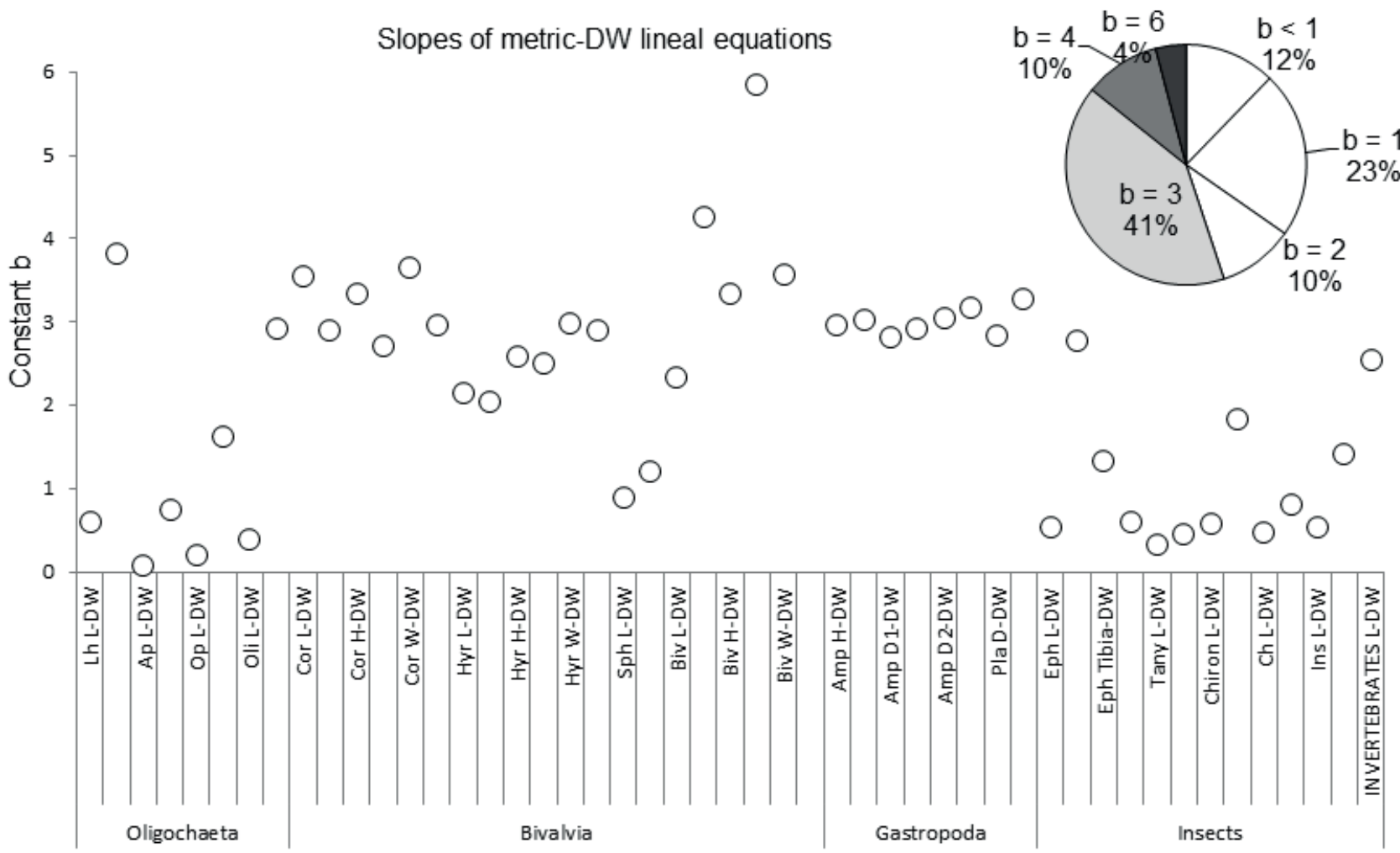

Fig. 8. Values of slopes $(=\mathrm{b})$ of regression equations obtained for metrics-DW relationships. Invertebrates were collected in the Paraná River floodplain from 2005 through 2014

become proportionately narrower as body length increases, or that specific gravity declines with size (BENKE et al., 1999). Certainly, slopes were much lower than 1 for all L-W regression equations (Appendix II).

Conversely, several equations for temperate or cold climate insects showed slopes relatively higher than ours, whereas they were relatively similar to the ones obtained for mollusks (several can be found in SMOCK, 1980; BURGHERR \& MEYER, 1997; BENKE et al., 1999). This is probably related to the fact that some tropical groups of insects have longer and thinner bodies than temperate ones (GowING \& RECHER, 1985). Moreover, slopes were relatively lower for regressions of dipterans than the ones obtained in cold environments of Patagonia (Argentina) whereas being relatively similar for Limnodrilus hoffmesiteri (MISERENDINO, 2001).

In relation to insects, Interoc-DW was close to 3 for mayflies, whereas for dipterans $\mathrm{cW}$-DW was relatively close to 1 . A reason for head-width regressions having $\mathrm{b}<$ 3 (e.g., Diptera), is that head width may be proportionately smaller in early instars than in later instar (BENKE et al., 1999).

When comparisons were assessed within our data set, slopes were all significantly higher for W-DW than for L-DW (Wilcoxon signed rank test, $\mathrm{p}<0.05$ ). When assessed within each taxa, we found that these differences were significant for worms and insects but not for mollusks (Kruskall-Wallis test $\mathrm{p}<0.05$, Mann-Whitney pairwise comparisons test $\mathrm{p}<$ $0.05)$. Additionally, slopes were significantly different for overall metrics-DW combined, among insects and worms with bivalves and gastropods that had the lower and higher slopes respectively (Kruskall-Wallis test $\mathrm{p}<0.05$, MannWhitney pairwise comparisons test $\mathrm{p}<0.05$ ).

Biomass and organic matter ratios. Allometric regressions are empirically determined and apply only to size ranges represented by actual data. Thus, when inferences are intended but data are out of range, is better to have proportions available. Therefore, several DW-L mean ratios \pm SE are presented on Appendix III. Additionally, also organic matter and biomass data (AFDW, WW and DW) mean ratios $\pm \mathrm{SE}$ are provided. WATERS (1977) approximated a value of $10 \%$ ash (or $90 \%$ organic matter) estimates for benthos and zooplankton. In our study, just some values for soft tissues of clams were around $90 \%$ organic matter, whereas leeches had percentages that fall below and worms and insects above it. For mollusks, the higher ash contents were obtained for the shells of clams, Sphaeriidae and planorbids due to exoesqueletons composition.

The AFDW/DW ratios were statistically different among taxa (Kruskal-Wallis test, $\mathrm{p}<0.01$ ) with significant differences mainly for leeches and all the other groups (Fig. 9). Indeed, predatory leeches showed a higher average organic matter proportion in relation to the other groups that feed mostly on basal resources such as apple snails that feed mostly on macrophytes and the other groups on detritus. Predators invest high part of their time in seeking for preys, whereas basal resources feeders can benefit from largely available and low-cost pursuing resources. However, predators consume a resource of high nutritious value (CUMMINS \& KLUG, 1979) 


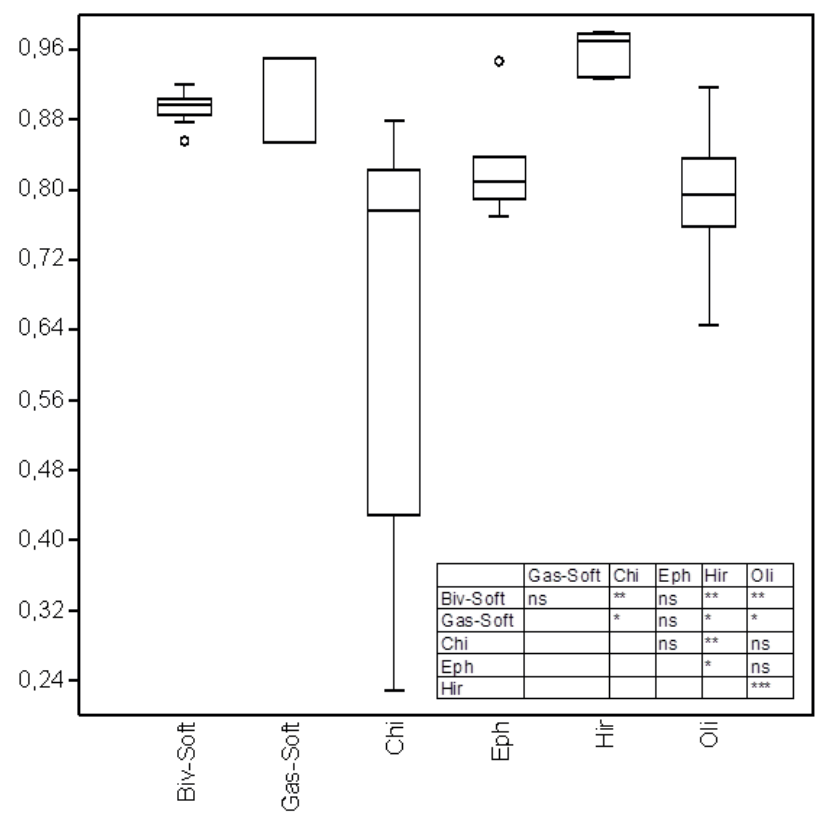

Fig. 9. Box-plot of invertebrates AFDW/DW. Significance values (p) of Mann-Whitney pairwise comparisons are showed on the lower-right side. P-values: * $\mathrm{p}=0.01-0.05 ; * * \mathrm{p}<0.01-0.001 ; * * * \mathrm{p}<0.001$. Invertebrates were collected in the Paraná River floodplain from 2005 through 2014.

and the assimilation rates of invertebrates are widely variable ranging from less than $5 \%$ for detritivores to almost $90 \%$ for predators (BeNKE \& Wallace, 1980). Therefore, our findings may support the idea that organic matter content of invertebrates is closely related to trade-offs involved in the type of feeding by invertebrates.

Final remarks. Simple lineal models proved to be very well adjusted for biomass estimations of invertebrates living in floodplain habitats of the Paraná River. Differences raised from variable growth types and phylogeny of invertebrates. Additionally, slopes differed from constants, mainly for insects obtained for other regions, climates and type of environments. Thus, we encourage other researchers to select equations from places as similar as possible in region, climatic zone and habitat characteristics to the communities being studied and from the closest taxonomic level to avoid errors associated with substitutions. Additionally, we consider that measuring any body structure of an invertebrate is less timeconsuming than to weight all the organisms collected and thus we encourage to use the information we provided whenever possible. When research is carried out on size ranges out of actual data, then we recommend to use proportions we provided. However, also significant differences were obtained mainly related to feeding types of different groups and thus we suggest to consider this issue when using proportions in either biodiversity or functional approaches.

Acknowledgements. This research was partially financially supported by PRESTAMO BID PICT 2012 N $^{\circ} 2791$, FONCyT, ANPCyT and PIP 11220130100318, CONICET, both MinCyT, Argentina.

\section{REFERENCES}

Albariño, R. \& Balseiro, E. 1998. Larval size and leaf conditioning in the breakdown of Nothofagus pumilio leaves by Klapopteryx kuscheli (Insecta, Plecoptera) in a South Andean Stream. Review of Hydrobiology 83:397-404.

Becker, B.; Moretti, M. S. \& Callisto, M. 2009. Length-dry mass relationships for a typical shredder in Brazilian streams (Trichoptera: Calamoceratidae). Aquatic Insects 31:227-234.

Benke, A. C.; Huryn, A. D.; Smock, L. A. \& Wallace, J. B. 1999. Lengthmass relationships for freshwater macroinvertebrates in North America with particular reference to the southeastern United States. Journal of the North American Benthological Society 18(3):308-343.

BenKe, A. C. \& Wallace, J. B. 1980. Trophic basis of production among net-spinning caddisflies in a southern Appalachian stream. Ecology 61:108-118.

Burgherr, P. \& Meyer, E. I. 1997. Regression analysis of linear body dimensions vs. dry mass in stream macroinvertebrates. Archiv für Hydrobiologie 139:101-112.

ButLer. M. G. 1984. Life histories of aquatic insects, In: Resh, V. H. \& Rosenberg, D. M. eds. The ecology of aquatic insects. New York, Praeger, p. 24-55.

CAMpbell, I. C. 1991. Size allometry in some australian mayfly nymphs (Insecta: Ephemeroptera). Aquatic Insects 13(2):79-86.

ClifFord, H. F. 1970. Analysis of a northern mayfly (Ephemeroptera) population, with special reference to allometry of size. Canadian Journal of Zoology 48:305-316.

CoLE, B. J. 1980. Growth ratios in holometabolous and hemimetabolous insects. Annals of the Entomological Society of America 73:489-491.

Cressa, C. 1986. Estimaciones de peso seco en función de la longitud cefálica y clases de tamaño en Campsurus sp. (Ephemeroptera, Polymitarcidae). Acta Científica Venezolana 37:170-173.

Cressa, C. 1999. Dry mass estimates of some tropical aquatic insects. Revista de Biología Tropical 47(1-2):133-141.

Cressa, C. \& Lewis JR., W. M. 1984. Growth and development patterns in a tropical Chaoborus species and their ecological significance. Archiv für Hydrobiologie 100:21-28.

Cummins, K. W. \& Klug M. J. 1979. Feeding ecology of stream invertebrates. Annual Review of Ecology and Systematics 10:147-172.

Donald, G. L. \& Paterson, C. G. 1977. Effect of preservation on wet weight biomass of chironomid larvae. Hydrobiologia 53:75-80.

Dyar, H. G. 1890. The number of molts of lepidopterous larvae. Psyche 5:420-422.

ENGELMAN, M. D. 1961. The role of soil arthropods in the energetics of an old field. Ecological Monographs 31(3):221-238.

Ezcurra de Drago, I.; Marchese, M. \& Montalto, L. 2007. Benthic invertebrates. In: Iriondo, H.; PAGgi, J. C. \& PARMA, M. J. eds. The Middle Paraná River Limnology of a Subtropical Wetland. New York, Springer- Verlag Berlin Heidelberg, p. 251-275.

Galizzi, C.; Zilli, F. L. \& MARCHESE, M. 2012. Diet and functional feeding groups of Chironomidae (Diptera) in the Middle Paraná River floodplain (Argentina). Iheringia, Série Zoologia 102:117-121.

GouLD, J. 1966. Allometry and size in ontogeny and phylogeny. Biological Reviews 41:587-640.

Gowing, G. \& ReCher, H. F. 1985. Further comments on length-weight relationships of invertebrates. Australian Journal of Ecology 10(2): 195 .

Gualdoni, C.; French, P.W. \& Oberto, A. M. 2013. Relaciones longitudbiomasa en macroinvertebrados bentónicos de un arroyo serrano del sur de Córdoba, Argentina. Ecología Austral 23:194-201.

Hammer, O.; Harper, D. A. T. \& Ryan, P.D. 2001. PAST. Paleontological Statistics software package for education and data analysis. Paleontología Electronica 4(1), 9p.

Johnston, T. A. \& CUNJAK, R. A. 1999. Dry mass-length relationships for benthic insects: a review with new data from Catamaran Brook, New Brunswick, Canada. Freshwater Biology 41:653-674.

Lappalainen, A. \& Kangas, P. 1975. Littoral benthos of the Northern Baltic Sea, 2. Interrelationships of wet, dry and ash-free dry weights 
of macro-fauna in the Tvarminne area. Internationale Revue der gesamten Hydrobiologie und Hydrographie 10:297-312.

Leuven, R. S. E. W.; Brocki, T. C. M. \& van Druten, H. A. M. 1985. Dry weight biomass of some common aquatic macroinvertebrates. Hydrobiologia 127:151-159.

López, C.; Corona, A.; Araujo, M. \& Rincón, J. 1997. Relaciones entre parámetros biométricos y peso seco en insectos acuáticos depredadores de Venezuela. Revista de Biología Tropical 45/46:641-643.

Meyer, E. 1989. The relationship between body length parameters and dry mass in running water invertebrates. Archiv für Hydrobiologie 117:191-203.

MiserEndinO, M. L. 2001. Length-mass relationships for macroinvertebrates in freshwater environments of Patagonia (Argentina). Ecología Austral 11:3-8.

Poi de NeIFF, A. \& NeIFF, J. J. 2006. Species richness and similarity of the invertebrates which live in floating plants on the floodplain of the River Parana Argentina. Interciencia 31(3):220-225.

Rogers, L. E.; Hinds, W. T. \& Buschbom, R. L. 1976. A general weight versus length relationship for Insects. Annals of the Entomological Society of America 69:387-389.

Saigo, M.; Zilli, F. L.; Marchese, M. R. \& Demonte, D. 2015. Trophic level, food chain length and omnivory in the Paraná River: a food web model approach in a floodplain river system. Ecological Research 30(5):843-852.

SCHOLL, D. A. 1954. Regularities in growth curves, including rhythms and allometry. In: BoElL, E. J. ed. Dynamics of growth processes. New Jersey, Princeton, p. 224-241.

Smock, L. A. 1980. Relationships between body size and biomass of aquatic insects. Freshwater Biology 10:375-383.

STIRN, J. 1981. Manual of methods in aquatic environment research. Part. 8. Ecological assesment of pollution effects. Rome, FAO Fish. tech. Pap. 209 (FIRI/T 209). 70p.
Towers , D. J.; Henderson, I. M. \& Veltman, C. J. 1994. Predicting dry weight of New Zealand aquatic macroinvertebrates from linear dimensions. New Zealand Journal of Marine and Freshwater Research 28(2):159-166.

VON BertalanfFy, L. 1964. Basic concepts in quantitative biology of metabolism. Helgol Wiss Meerensunters 9(1-4):1-37.

WAters, T. F. 1977. Secondary production in inland waters. Advances in Ecological Research 10:91-164.

Wenzel, F; Meyer, E. \& Schwoerbel, J. 1990. Morphometry and biomass determination of dominant mayfly larvae (Ephemeroptera) in running waters. Archiv für Hydrobiologie 118:31-46.

ZAR, J. H. 1999. Biostatistical Analysis. New Jersey, Prentice-Hall. 663p.

ZILLI, F. L. 2013. Distribution of benthic invertebrate biomass and secondary production in relation to floodplain connectivity in a large river system (Paraná River, Argentina). International Review of Hydrobiology 98:1-10.

ZILLI, F. L. 2012. Life history traits and secondary production of Campsurus violaceus (Ephemeroptera: Polymitarcyidae) in the Paraná River floodplain lakes, Argentina. Studies on Neotropical Fauna and Environment 47:61-71.

Zilli, F. L.; Montalto, L.; Paggi, A. C. \& Marchese, M. R. 2008. Biometry and life cycle of Chironomus calligraphus Goeldi, 1905 (Diptera, Chironomidae) in laboratory conditions. Interciencia 33:767770 .

Zilli, F. L.; Marchese, M. R. \& Paggi A. C. 2009. Life Cycle of Goeldichironomus holoprasinus Goeldi (Diptera, Chironomidae). Neotropical Entomology 38(4):472-476.

ZILLI, F. L. \& PAGGI, A. C. 2013. Ecological responses to different degrees of hydrologic connectivity: Assessing patterns in the bionomy of benthic chironomids in a Large River-Floodplain System. Wetlands 33:837-845. 
Appendix I. Lineal coefficients obtained for each equation of the linear regression for the conversion of lineal metrics (mm) into dry mass (mg, DW) for the Paraná River floodplain (Argentina) macroinvertebrates. Data (n), metric ranges and $\mathrm{R}^{2}$ values calculated are showed. Significance level (p), was always $<0.01$.

\begin{tabular}{|c|c|c|c|c|c|c|c|}
\hline \multirow[t]{2}{*}{ Taxa } & \multirow{2}{*}{$\begin{array}{l}\mathrm{x}-\mathrm{y} \text { measurements } \\
\text { used in the calcula- } \\
\text { tions }\left(\log _{10}\right)\end{array}$} & \multicolumn{6}{|c|}{ Regression constants } \\
\hline & & $\log 10 \mathrm{a}$ & $\mathrm{b}$ & $p$ & $\mathrm{R}^{2}$ & $\mathrm{n}$ & Metric range $(\mathrm{mm})$ \\
\hline \multirow{2}{*}{ Limnodrilus spp. } & L-DW & $0.62 \pm 0.05$ & $0.65 \pm 0.04$ & $* * *$ & 0.916 & 25 & $2.70-33.58$ \\
\hline & W-DW & $-0.23 \pm 0.02$ & $3.83 \pm 0.21$ & $* * *$ & 0.890 & 41 & $0.11-0.58$ \\
\hline \multirow{2}{*}{ Aulodrilus pigueti } & L-DW & $-0.04 \pm 0.01$ & $0.08 \pm 0.02$ & $* * *$ & 0.550 & 25 & $2.30-11.00$ \\
\hline & W-DW & $-0.02 \pm 0.01$ & $0.75 \pm 0.15$ & $* * *$ & 0.488 & 29 & $0.13-0.35$ \\
\hline \multirow{2}{*}{ Opistocystidae } & L-DW & $-0.10 \pm 0.04$ & $0.20 \pm 0.04$ & $* * *$ & 0.570 & 19 & $4.04-10.05$ \\
\hline & W-DW & $-0.10 \pm 0.05$ & $1.63 \pm 0.47$ & $* *$ & 0.506 & 17 & $0.20-0.34$ \\
\hline \multirow{2}{*}{ Oligochaetes combined } & L-DW & $-0.30 \pm 0.03$ & $0.39 \pm 0.03$ & $* * *$ & 0.728 & 69 & $2.30-33.58$ \\
\hline & W-DW & $-0.18 \pm 0.02$ & $2.93 \pm 0.23$ & $* * *$ & 0.662 & 87 & $0.11-0.58$ \\
\hline \multirow{6}{*}{ Corbiculidae } & L-DW & $-1.18 \pm 0.06$ & $3.54 \pm 0.06$ & $* * *$ & 0.989 & 40 & $8.28-14.66$ \\
\hline & L-DWSoft & $-2.03 \pm 0.09$ & $2.90 \pm 0.08$ & $* * *$ & 0.970 & 42 & $8.28-14.66$ \\
\hline & H-DW & $-0.88 \pm 0.05$ & $3.34 \pm 0.05$ & $* * *$ & 0.993 & 41 & $7.51-14.35$ \\
\hline & H-DWSoft & $-1.76 \pm 0.10$ & $2.72 \pm 0.10$ & $* * *$ & 0.948 & 43 & $7.51-14.35$ \\
\hline & W-DW & $-0.74 \pm 0.06$ & $3.65 \pm 0.06$ & $* * *$ & 0.989 & 40 & $5.49-10.24$ \\
\hline & W-DWSoft & $-1.64 \pm 0.09$ & $2.97 \pm 0.10$ & $* * *$ & 0.955 & 43 & $5.49-10.24$ \\
\hline \multirow{6}{*}{ Hyriidae } & L-DW & $0.42 \pm 0.41$ & $2.15 \pm 0.23$ & $* * *$ & 0.905 & 11 & $23.75-93.96$ \\
\hline & L-DWSoft & $0.58 \pm 0.42$ & $2.04 \pm 0.24$ & $* * *$ & 0.890 & 11 & $23.75-93.96$ \\
\hline & H-DW & $0.30 \pm 0.53$ & $2.58 \pm 0.36$ & $* * *$ & 0.854 & 11 & $16.01-57.29$ \\
\hline & H-DWSoft & $0.39 \pm 0.47$ & $2.50 \pm 0.32$ & $* * *$ & 0.873 & 11 & $16.01-57.29$ \\
\hline & W-DW & $0.16 \pm 0.66$ & $2.98 \pm 0.49$ & $* * *$ & 0.802 & 11 & $11.01-38.99$ \\
\hline & W-DWSoft & $0.24 \pm 0.60$ & $2.89 \pm 0.45$ & $* * *$ & 0.824 & 11 & $11.01-38.99$ \\
\hline \multirow{2}{*}{ Sphaeriidae $^{* 1}$} & L-DW & $-0.28 \pm 0.11$ & $0.90 \pm 0.18$ & $* * *$ & 0.480 & 29 & $1.83-5.11$ \\
\hline & H-DW & $-0.36 \pm 0.11$ & $1.21 \pm 0.21$ & $* * *$ & 0.542 & 29 & $1.20-3.88$ \\
\hline \multirow{6}{*}{ Bivalves combined $^{* 2}$} & L-DW & $0.11 \pm 0.06$ & $2.34 \pm 0.05$ & $* * *$ & 0.981 & 51 & $8.28-93.96$ \\
\hline & L-DWSoft & $-3.43 \pm 0.15$ & $4.26 \pm 0.12$ & $* * *$ & 0.959 & 53 & $8.28-93.96$ \\
\hline & H-DW & $-0.86 \pm 0.09$ & $3.33 \pm 0.08$ & $* * *$ & 0.975 & 51 & $7.51-57.29$ \\
\hline & H-DWSoft & $-4.95 \pm 0.30$ & $5.85 \pm 0.26$ & $* * *$ & 0.907 & 54 & $7.51-57.29$ \\
\hline & W-DW & $-0.65 \pm 0.80$ & $3.56 \pm 0.08$ & $* * *$ & 0.975 & 51 & $3.18-38.99$ \\
\hline & W-DWSoft & $-4.65 \pm 0.26$ & $6.33 \pm 0.25$ & $* * *$ & 0.925 & 54 & $4.12-38.99$ \\
\hline \multirow{6}{*}{ Ampullariidae } & H-DW & $-1.01 \pm 0.10$ & $2.96 \pm 0.08$ & $* * *$ & 0.952 & 69 & $1.55-84.73$ \\
\hline & H-DWSoft & $-1.76 \pm 0.20$ & $3.02 \pm 0.15$ & $* * *$ & 0.949 & 24 & $6.65-84.73$ \\
\hline & D1-DW & $0.59 \pm 0.09$ & $2.82 \pm 0.08$ & $* * *$ & 0.947 & 69 & $1.47-78.02$ \\
\hline & D1-DWSoft & $-1.39 \pm 0.20$ & $2.92 \pm 0.15$ & $* * *$ & 0.942 & 24 & $5.39-78.02$ \\
\hline & D2-DW & $-0.71 \pm 0.08$ & $3.05 \pm 0.07$ & $* * *$ & 0.963 & 69 & $1.30-59.45$ \\
\hline & D2-DWSoft & $-1.54 \pm 0.16$ & $3.18 \pm 0.13$ & $* * *$ & 0.963 & 24 & $4.7-59.45$ \\
\hline Planorbidae & D-DW & $-1.11 \pm 0.07$ & $2.84 \pm 0.14$ & $* * *$ & 0.912 & 44 & $1.53-3.33$ \\
\hline Gastropoda combined & $\mathrm{D}^{* 3}-\mathrm{DW}$ & $-1.18 \pm 0.06$ & $3.28 \pm 0.06$ & $* * *$ & 0.965 & 113 & $1.41-78.02$ \\
\hline \multirow{3}{*}{ Ephemeroptera } & L-DW & $-0.27 \pm 0.007$ & $0.53 \pm 0.01$ & $* * *$ & 0.908 & 503 & $1.48-19$ \\
\hline & Interoc-DW & $-0.11 \pm 0.005$ & $2.78 \pm 0.05$ & $* * *$ & 0.853 & 474 & $0.07-0.55$ \\
\hline & Tibia-DW & $-0.12 \pm 0.005$ & $1.33 \pm 0.02$ & $* * *$ & 0.879 & 474 & $0.16-1.63$ \\
\hline \multicolumn{8}{|l|}{ Chironomidae } \\
\hline Coelotanypus spp. & L-DW & $-0.43 \pm 0.07$ & $0.61 \pm 0.08$ & $* * *$ & 0.772 & 20 & $4.08-9.13$ \\
\hline \multirow{2}{*}{ Tanypodinae combined } & L-DW & $-0.20 \pm 0.03$ & $0.33 \pm 0.04$ & $* * *$ & 0.557 & 56 & $1.6-9.88$ \\
\hline & $\mathrm{cW}-\mathrm{DW}$ & $-0.11 \pm 0.03$ & $1.01 \pm 0.21$ & $* * *$ & 0.352 & 46 & $0.23-0.73$ \\
\hline \multirow{2}{*}{ Chironominae combined } & L-DW & $-0.37 \pm 0.07$ & $0.57 \pm 0.09$ & $* * *$ & 0.557 & 33 & $2.05-21.75$ \\
\hline & $\mathrm{cW}-\mathrm{DW}$ & $-0.14 \pm 0.05$ & $1.84 \pm 0.40$ & $* * *$ & 0.416 & 32 & $0.11-0.78$ \\
\hline \multirow{2}{*}{ Chironomidae combined } & L-DW & $-0.31 \pm 0.04$ & $0.48 \pm 0.05$ & $* * *$ & 0.521 & 89 & $1.6-21.75$ \\
\hline & $\mathrm{cW}-\mathrm{DW}$ & $-0.10 \pm 0.03$ & $1.14 \pm 0.22$ & $* * *$ & 0.267 & 78 & $0.11-0.73$ \\
\hline \multirow{2}{*}{ Insects combined } & L-DW & $-0.28 \pm 0.008$ & $0.53 \pm 0.01$ & $* * *$ & 0.817 & 592 & $1.48-21.75$ \\
\hline & Width $^{* 4}$-DW & $-0.04 \pm 0.009$ & $1.69 \pm 0.09$ & $* * *$ & 0.410 & 552 & $0.07-0.73$ \\
\hline Invertebrates combined & L-DW & $-1.70 \pm 0.09$ & $2.55 \pm 0.10$ & $* * *$ & 0.477 & 775 & $0.39-93.96$ \\
\hline
\end{tabular}


Appendix II. Lineal coefficients obtained for each equation of the linear regression for the conversion of lineal metrics (mm) into other linear metrics (mm) for the Paraná River floodplain (Argentina) macroinvertebrates. Data (n), metric ranges and $\mathrm{R}^{2}$ values calculated are showed. Significance level (p), was always $<0.01$.

\begin{tabular}{|c|c|c|c|c|c|c|c|}
\hline Taxa & $\begin{array}{l}x-y \text { measurements } \\
\text { used in the } \\
\text { calculations }\left(\log _{10}\right)\end{array}$ & \multicolumn{2}{|c|}{ Regression constants } & $p$ & $\mathrm{R}^{2}$ & $\mathrm{n}$ & Metric range $(\mathrm{mm})$ \\
\hline & & $\log 10 \mathrm{a}$ & $\mathrm{b}$ & & & & \\
\hline Limnodrilus spp. & L-W & $-0.01 \pm 0.01$ & $0.10 \pm 0.01$ & $* * *$ & 0.561 & 53 & $2.70-33.58$ \\
\hline Oligochaetes combined & L-W & $0.04 \pm 0.01$ & $0.06 \pm 0.01$ & $* * *$ & 0.228 & 85 & $2.30-33.58$ \\
\hline \multirow{3}{*}{ Corbiculidae } & L-H & $-0.098 \pm 0.02$ & $1.07 \pm 0.02$ & $* * *$ & 0.982 & 42 & \multirow{2}{*}{$6.33-14.66$} \\
\hline & $\mathrm{L}-\mathrm{W}$ & $-0.12 \pm 0.02$ & $0.97 \pm 0.02$ & $* * *$ & 0.988 & 42 & \\
\hline & $\mathrm{H}-\mathrm{W}$ & $-0.04 \pm 0.02$ & $0.91 \pm 0.02$ & $* * *$ & 0.989 & 43 & $5.50-14.35$ \\
\hline \multirow{3}{*}{ Hyriidae } & L-H & $0.33 \pm 0.26$ & $0.67 \pm 0.15$ & $* *$ & 0.682 & 11 & \multirow{2}{*}{$23.75-93.96$} \\
\hline & L-W & $0.47 \pm 0.27$ & $0.50 \pm 0.15$ & $* *$ & 0.545 & 11 & \\
\hline & $\mathrm{H}-\mathrm{W}$ & $0.14 \pm 0.12$ & $0.81 \pm 0.08$ & $* * *$ & 0.922 & 11 & $16.01-57.29$ \\
\hline Sphaeriidae & L-H & $0.03 \pm 0.04$ & $0.80 \pm 0.07$ & $* * *$ & 0.84 & 30 & $1.83-5.11$ \\
\hline \multirow{3}{*}{ Bivalves combined } & L-H & $0.03 \pm 0.02$ & $0.89 \pm 0.02$ & $* * *$ & 0.949 & 83 & $1.83-93.96$ \\
\hline & $\mathrm{L}-\mathrm{W}$ & $0.23 \pm 0.03$ & $0.64 \pm 0.02$ & $* * *$ & 0.932 & 53 & $6.33-93.96$ \\
\hline & $\mathrm{H}-\mathrm{W}$ & $-0.05 \pm 0.02$ & $0.93 \pm 0.01$ & $* * *$ & 0.987 & 54 & $1.20-57.29$ \\
\hline \multirow{3}{*}{ Ampullariidae } & H-D1 & $-0.07 \pm 0.01$ & $0.99 \pm 0.01$ & $* * *$ & 0.991 & 83 & \multirow{2}{*}{$1.55-84.73$} \\
\hline & H-D2 & $-0.07 \pm 0.01$ & $0.95 \pm 0.01$ & $* * *$ & 0.993 & 83 & \\
\hline & D1-D2 & $0.01 \pm 0.01$ & $0.96 \pm 0.01$ & $* * *$ & 0.993 & 83 & $1.47-78.02$ \\
\hline \multirow{3}{*}{ Ephemeroptera } & L-Tibia & $-0.09 \pm 0.004$ & $0.37 \pm 0.005$ & $* * *$ & 0.932 & 474 & \multirow{2}{*}{$1.48-16.88$} \\
\hline & L-Interoc & $-0.04 \pm 0.002$ & $0.16 \pm 0.002$ & $* * *$ & 0.907 & 474 & \\
\hline & Tibia-Interoc & $-0.0001 \pm 0.0007$ & $0.46 \pm 0.003$ & $* * *$ & 0.977 & 474 & $0-16-1.63$ \\
\hline Tanypodinae & L-cW & $0.05 \pm 0.03$ & $0.16 \pm 0.04$ & $* * *$ & 0.239 & 52 & $1.60-9.88$ \\
\hline Chironominae & $\mathrm{L}-\mathrm{W}$ & $-0.07 \pm 0.02$ & $0.24 \pm 0.02$ & $* * *$ & 0.76 & 32 & $2.05-21.75$ \\
\hline Chironomidae combined & $\mathrm{L}-\mathrm{W}$ & $-0.01 \pm 0.02$ & $0.21 \pm 0.03$ & $* * *$ & 0.371 & 84 & $1.6-21.75$ \\
\hline Insects combined & L-Width $^{* 1}$ & $-0.03 \pm 0.005$ & $0.17 \pm 0.006$ & $* * *$ & 0.569 & 558 & $1.48-21.75$ \\
\hline
\end{tabular}

* 1 Width represented by $\mathrm{CW}$ for midges and Interoc for mayflies 
Appendix III. Mean weight ratios ( \pm SE) of invertebrate taxa. $\mathrm{N}$ represent either individual (when not specified) or pools of them.

\begin{tabular}{|c|c|c|c|}
\hline & Mean & $\pm \mathrm{SE}$ & $\mathrm{N}$ \\
\hline Sph DW/WW & 0.45 & 0.07 & 5 pools of $\approx 110$ individuals each \\
\hline Sph AFDW/DW & 0.82 & 0.03 & “" \\
\hline Sph H/L & 0.753 & 0.01 & 31 \\
\hline Sph DW/L (mg/mm) & 0.302 & 0.03 & 32 \\
\hline Cor DW/WW & 0.69 & 0.002 & 40 \\
\hline Cor Soft DW/WW & 0.17 & 0.004 & 44 \\
\hline Cor Soft AFDW/DW & 0.89 & 0.005 & 3 pools of $\approx 32$ individuals each \\
\hline Cor Shell AFDW/DW & 0.03 & 0.003 & 4 pools of $\approx 53$ valves each \\
\hline Cor DW Soft/all & 0.03 & 0.0005 & 41 \\
\hline Cor DW Soft/Shell & 0.03 & 0.0005 & “" \\
\hline Cor DW Soft/L (mg/mm) & 1.065 & 0.06 & 45 \\
\hline Cor W/L & 0.671 & 0.003 & 44 \\
\hline Cor $\mathrm{H} / \mathrm{L}$ & 0.939 & 0.004 & “ \\
\hline Cor W/H & 0.715 & 0.002 & 45 \\
\hline Hyr DW/WW & 0.66 & 0.04 & 11 \\
\hline Hyr Soft DW/WW & 0.76 & 0.01 & “ \\
\hline Hyr Soft AFDW/DW & 0.89 & 0.01 & 7 \\
\hline Hyr Shell AFDW/DW & 0.05 & 0.00 & “" \\
\hline Hyr DW Soft/all & 0.92 & 0.03 & “" \\
\hline Hyr DW Soft/L (mg/mm) & 287.0 & 51.18 & 11 \\
\hline Hyr W/L & 0.4 & 0.05 & “" \\
\hline Hyr H/L & 0.6 & 0.05 & “" \\
\hline Hyr W/H & 0.7 & 0.03 & “" \\
\hline Amp DW/WW & 0.42 & 0.01 & 69 \\
\hline Amp Soft DW/WW & 0.31 & 0.02 & 4 \\
\hline Amp Soft AFDW/DW & 0.89 & 0.02 & “" \\
\hline Amp Soft AFDW/WW & 0.27 & 0.02 & “" \\
\hline Amp Shell AFDW/DW & 0.05 & 0.01 & 3 \\
\hline Amp DW Soft/all & 0.22 & 0.01 & 24 \\
\hline Amp DW/H & 65.01 & 18.27 & 67 \\
\hline Amp D1/D2 & 1.13 & 0.01 & 83 \\
\hline Amp H/D1 & 1.24 & 0.01 & “" \\
\hline Amp H/D2 & 1.40 & 0.01 & “" \\
\hline Pla DW/WW & 0.32 & 0.01 & 48 \\
\hline Pla AFDW/DW & 0.27 & $\mathrm{x}$ & 2 \\
\hline Plano DW/D & 0.50 & 0.05 & 48 \\
\hline Ch DW/WW & 0.47 & 0.17 & 3 pools of $\approx 68$ individuals each \\
\hline Ch AFDW/DW & 0.63 & 0.10 & “" \\
\hline Tany ccW/L & 0.09 & 0.01 & 56 \\
\hline Tany DW/L & 0.02 & 0.003 & “" \\
\hline Chir ccW/L & 0.06 & 0.003 & 31 \\
\hline Chir DW/L & 0.01 & 0.002 & 30 \\
\hline Eph DW/WW & 0.49 & $\mathrm{x}$ & 2 pools of $\approx 19$ individuals each \\
\hline Eph AFDW/DW & 0.83 & 0.03 & “ \\
\hline Eph DW/L & 0.161 & 0.004 & 503 \\
\hline Eph Tibia/L & 0.243 & 0.002 & 474 \\
\hline Eph interoc/L & 0.113 & 0.001 & “" \\
\hline Hir DW/WW & 0.42 & 0.07 & 7 pools of $\approx 41$ individuals each \\
\hline Hir AFDW/DW & 0.96 & 0.01 & “" \\
\hline Oli DW/WW & 0.50 & 0.05 & 13 pools of $\approx 163$ individuals each \\
\hline Oli AFDW/DW & 0.79 & 0.02 & “" \\
\hline Ap W/L & 0.03 & 0.002 & 33 \\
\hline Ap DW/L & 0.01 & 0.001 & 34 \\
\hline $\mathrm{Op} \mathrm{W/L}$ & 0.04 & 0.004 & 21 \\
\hline Op DW/L & 0.03 & 0.002 & “ \\
\hline Lim W/L & 0.02 & 0.001 & 52 \\
\hline Lim DW/L & 0.02 & 0.002 & 51 \\
\hline
\end{tabular}

